\title{
THE USE OF SERVPERF METHOD IN EVALUATION OF TRANSLATION SERVICES
}

\begin{abstract}
The Servperf method (Service Performance) is an interesting method of the service quality analysis. It was created as a contrast proposal to the Servqual method. The purpose of this chapter is to assess quality of services offered by one translation office which is located in Czestochowa. For this purpose, the method Servperf, which in contrast to other methods for assessing the quality of services, takes into account only the perception of the service, and thus avoids the subjectivity of the assessment from the side of customers. The research took the form of survey, which was filled in on the Internet by customers of the translation office, after delivery of its services. Translation services are very popular popularity recently, while competition in the market is large. Therefore, customers are looking for information on the quality of such services.
\end{abstract}

Key words: service quality, Servperf, translation services

\section{Introduction}

In the era of open borders, frequent trips and developed international cooperation, in many cases there is a need to translate large amounts of text, official documents, technical documentation etc. Often, these translations must take the form of a sworn translation. That is why the translation services are very popular recently, while competition in the market is very large. Therefore it is good before choosing such company to consult or search for information on the quality of their services.

The translational services, like other services, are not easy to be assessed in terms of their quality. It is impossible to specify the exact features, which should be characterized, therefore, to assess them, it is good to use any of the methods for assessing the quality of services. One

1 Dr inż., Czestochowa University of Technology, Faculty of Management, Institute of Production Engineering, e-mail: manuela@gazeta.pl 
of such methods is Servperf method, which examines only the level of quality of the received, realized service (perception), and compares it to the ideal services (INGALDI M.20015a) (INGALDI M. 215b).

The purpose of this chapter is to assess quality of services offered by one translation office which is located in Czestochowa. For this purpose, the method Servperf, which in contrast to other methods for assessing the quality of services, takes into account only the perception of the service, and thus avoids the subjectivity of the assessment from the side of customers. The research took the form of survey, which was filled in on the Internet by customers of the translation office, after using its services.

\section{Description of the Serfperv method}

The Servperf method (Service Performance) is an interesting method of the service quality analysis. It was created as a contrast proposal to the Servqual method.

The basic assumption the Servperf method is to improve the service quality. It was created by Cronin and Taylor, who found out that we cannot examine customer expectations, because the expectations belong to the ambiguous and variable category. They can change very easily. The Servperf method, unlike the method Servqual, examines only the level of quality of the received, realized service (perception), and compares it to the ideal services (STOMA M., 2012). This method gets rid of the subjectivity, because the customer does not specify in advance its often unreasonable expectations about the service.

The general formula of the method is very easy, which from a practical point of view makes it easier to apply. The service quality is compared to customer perception (KUCIŃSKA A. 2007); (KUCIŃSKA A., KoŁosowsKi M. 2009). This method is therefore easier to use and less time-consuming compared to the Servqual method (GILMORE A. 2003).

Evaluation and measurement of the quality service in the Servperf method is based on determinants derived from the Servqual method. 
Measurement of the service quality is made with a seven semantic rating scale (Likert scale), where the lowest level of the scale is: weak, and the best: excellent - so similar like in the Servqual method. The better service quality examined by this method is, the closer the individual scores to the maximum value is (GARCZARCZYK J. 2000).

\section{Metodology}

In chosen translation office the survey aimed at assessing the quality of services offered and performed by this office was conducted. The research included the customer of the chosen translation office after they used the services of the chosen translation office. The research involved 97 customers.

The research had a form of the Internet survey about which fulfilment were asked customers after using the services offered by the research company. Electronic form of the survey provides greater anonymity and facilitates data collection and sorting of results.

In Table 1 all determinants, which were evaluated during the research, divided into five basic groups, were presented. In Table 2 the original part of the original survey about empathy of the staff with its determinants were shown. The customers were supposed to evaluate every determinant according to the Liker's scale presented in this Table, where 1 means "I disagree" and 7 means "I agree". Table 3 includes weights of all individual groups of determinants (also part of the original survey). The respondents had to divide 100 points between the individual groups. 
Table 1. Statement in the survey Servperf

\begin{tabular}{|c|c|c|}
\hline No & Group & Statement (determinant) \\
\hline 1. & \multirow{5}{*}{ 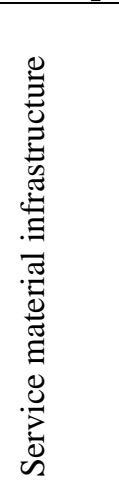 } & $\begin{array}{l}\text { The research translation office is conveniently located, } \\
\text { and access to it is easy. }\end{array}$ \\
\hline 2. & & $\begin{array}{l}\text { Building of the research translation office is attractive, } \\
\text { encourages to enter. }\end{array}$ \\
\hline 3. & & $\begin{array}{l}\text { Close to the research translation office there is a parking } \\
\text { lot with sufficient parking spaces. }\end{array}$ \\
\hline 4. & & $\begin{array}{l}\text { The research translation office has a well-organized } \\
\text { website. }\end{array}$ \\
\hline 5. & & $\begin{array}{l}\text { In the research translation office customers can place } \\
\text { orders and settle over the Internet. }\end{array}$ \\
\hline 6. & \multirow{5}{*}{ 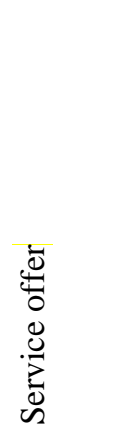 } & $\begin{array}{l}\text { Offer of the research translation office is very broad in } \\
\text { terms of languages. }\end{array}$ \\
\hline 7. & & $\begin{array}{l}\text { The research translation office also performs sworn } \\
\text { translations. }\end{array}$ \\
\hline 8. & & $\begin{array}{l}\text { The research translation office also performs specialized } \\
\text { translations. }\end{array}$ \\
\hline 9. & & $\begin{array}{l}\text { The research translation office also performs oral } \\
\text { translations. }\end{array}$ \\
\hline 10. & & Offer of the research translation office is up to date. \\
\hline 11. & \multirow{5}{*}{ 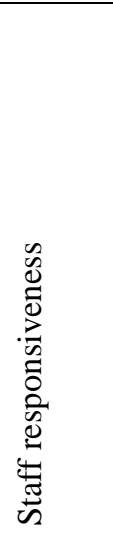 } & $\begin{array}{l}\text { Interpreters working in the research translation office } \\
\text { have appropriate education and qualifications to do their } \\
\text { job. }\end{array}$ \\
\hline 12. & & $\begin{array}{l}\text { The research translation office runs flawlessly } \\
\text { documentation. }\end{array}$ \\
\hline 13. & & $\begin{array}{l}\text { The research translation office performs each order in } \\
\text { time in which it has committed. }\end{array}$ \\
\hline 14. & & $\begin{array}{l}\text { The research translation office keeps the conditions of the } \\
\text { concluded contract. }\end{array}$ \\
\hline 15. & & $\begin{array}{l}\text { Employees of the research translation office have } \\
\text { adequate knowledge of the offered services. }\end{array}$ \\
\hline
\end{tabular}




\begin{tabular}{|c|c|c|}
\hline 16. & \multirow{3}{*}{ 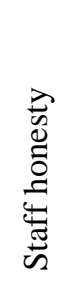 } & $\begin{array}{l}\text { Employees of the research translation office are nice and } \\
\text { polite. }\end{array}$ \\
\hline 17. & & $\begin{array}{l}\text { Employees of the research translation office are } \\
\text { communicative. }\end{array}$ \\
\hline 18. & & $\begin{array}{l}\text { Employees of the research translation office have a neat } \\
\text { appearance. }\end{array}$ \\
\hline 19. & \multirow{3}{*}{ 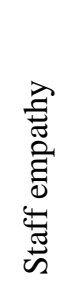 } & $\begin{array}{l}\text { Employees of the research translation office respond } \\
\text { quickly to customer requests. }\end{array}$ \\
\hline 20. & & $\begin{array}{l}\text { Employees of the research translation office understand } \\
\text { the specific needs of customers. }\end{array}$ \\
\hline 21. & & $\begin{array}{l}\text { Opening hours the research translation office are } \\
\text { convenient for customers. }\end{array}$ \\
\hline
\end{tabular}

Source: own study

Table 2. Evaluation of chosen group of determinants - part of the original

\begin{tabular}{|c|c|c|c|c|c|c|c|c|}
\hline \multicolumn{9}{|c|}{ survey } \\
\hline & \multirow[t]{2}{*}{ Statement (determinant) } & \multicolumn{7}{|c|}{$\begin{array}{l}\text { Evaluation according to Liker's } \\
\text { scale }\end{array}$} \\
\hline & & 1 & 2 & 3 & 4 & 5 & 6 & 7 \\
\hline \multirow{3}{*}{ 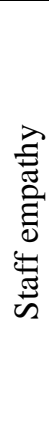 } & $\begin{array}{l}\text { Employees of the research } \\
\text { translation office respond quickly } \\
\text { to customer requests. }\end{array}$ & & & & & & & \\
\hline & $\begin{array}{l}\text { Employees of the research } \\
\text { translation office understand the } \\
\text { specific needs of customers. }\end{array}$ & & & & & & & \\
\hline & $\begin{array}{l}\text { Opening hours the research } \\
\text { translation office are convenient } \\
\text { for customers. }\end{array}$ & & & & & & & \\
\hline
\end{tabular}

Source: own study 
Table 3. Weight of individual groups of determinants - part of the original

\begin{tabular}{|l|l|}
\multicolumn{2}{|c|}{ survey } \\
\hline Group of determinants & Number of points \\
\hline Service material infrastructure & \\
\hline Service offer & \\
\hline Staff responsiveness & \\
\hline Staff honesty & \\
\hline Staff empathy & \\
\hline
\end{tabular}

Source: own study

In case of each individual determinant, the average evaluation was calculated. Only these results were presented in the graphical way. Different type of graphic forms were used. At the beginning with use of the histogram the average values for each determinant were presented, to identify those that got the highest evaluations. Then with use of the same kind of graphic the comparison of the average value of individual determinant was compared to ideal evaluation (percentage fraction to evaluation 7). Then with use of the reversed histograms, wages and average values for each group of determinants were presented. The arithmetic average and the weighted average for all determinants were calculated and then they were compared to ideal evaluation. For the calculation of the weighted average, weights of the individual groups of determinants were used.

\section{Characteristics of the research object}

The research was conducted in the translation office $\mathrm{X}$, which is located in Czestochowa. This office has been operating since the early nineties. Nowadays the research office employs over 20 translators with the identified qualifications and 6 native speakers and proofreaders specializing in various types of texts. It is not a large office, but has a certain reputation in the market. 
The main customers of the translation offices are schools and colleges, universities, government offices, judicial institutions, law firms and patent traders, from Poland and abroad, and individuals customers.

Offer of translation of texts and documents relates to more than 10 languages. Translation includes: ordinary translations, sworn translations, specialized translation, translation of documents, vehicle registration, translation of technical documentation, tender documents, translation of business correspondence, complaints, marketing texts, creative translations of websites, applications, etc., proofreading.

\section{Results}

In Figure 1 the average values of evaluations given by respondents to individual determinants were presented. While in Figure 2 these value were compared to the ideal evaluation (evaluation in Liker's scale).

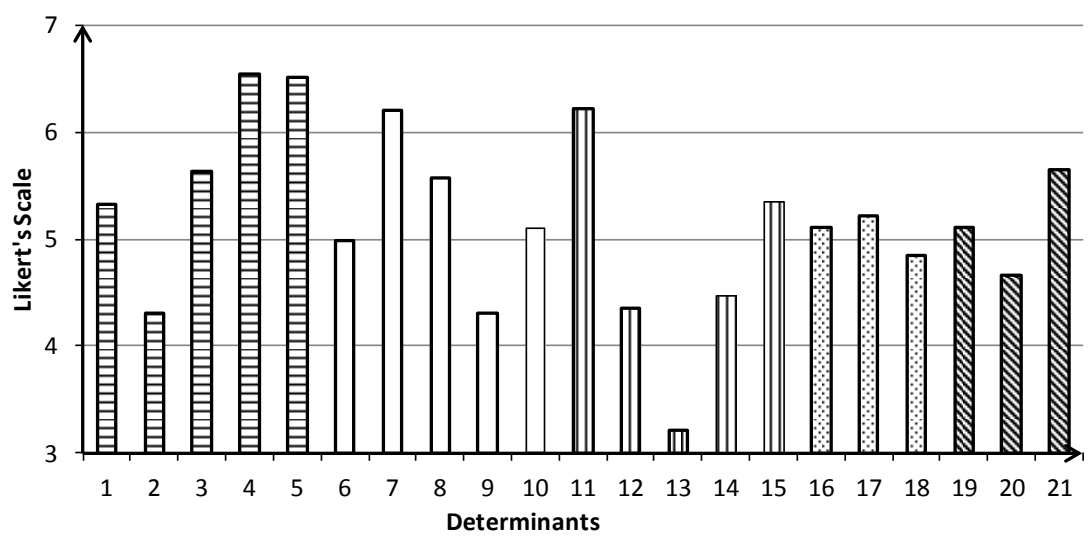

Fig. 1. Aggregated results for the Servperf method.

Source: own study 


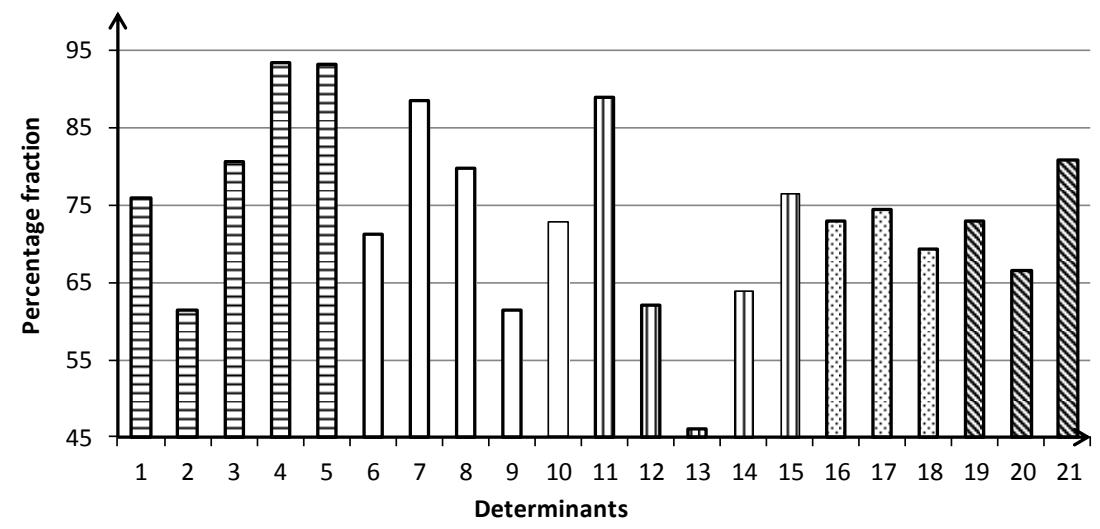

Fig. 2. Percentage in relation to the Likert's scale for the Servperf method. Source: own study

Analyzing Figure 1 and 2 it can be immediately noted that none of the statements in the research translation office has not been evaluated below 3 .

The highest evaluations were gives in case of following statements: statement 4 , that the research translation office has a well-organized website; statement 5, that in the research translation office customers can place orders and settle over the Internet; statement 7, that the research translation office also performs sworn translations and statement 11, that interpreters working in the research translation office have appropriate education and qualifications to do their job. This means that customers positively assess the website of the research office and contact with the office through this website. For customers it is also important that the office performs sworn translations and employs very good interpreters.

The same time the customers gave the lowest evaluation to the statement 13 , that the research translation office performs each order in time in which it has committed. Perhaps the research translation office is not always prepared to fulfill its agreements at a predetermined time, or 
customers expected earlier than specified in the contract to have the service delivered.

In Figure 3 weights of each group of determinant given by respondent were presented while in Figure 4 average values of each group were shown.

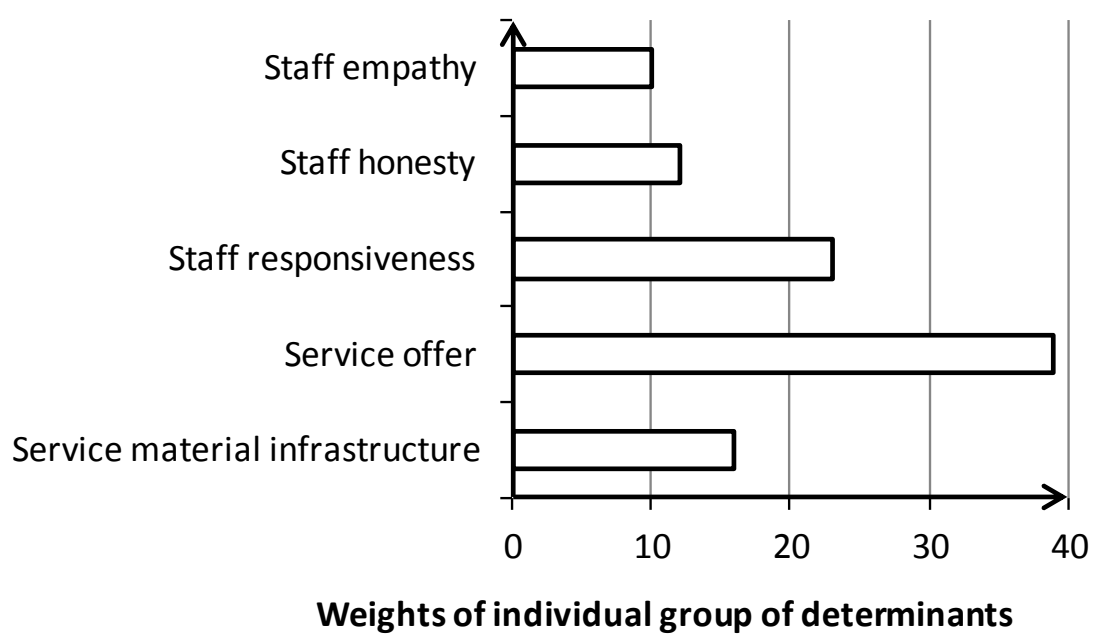

Fig. 3. Weights of individual group of determinants.

Source: own study 


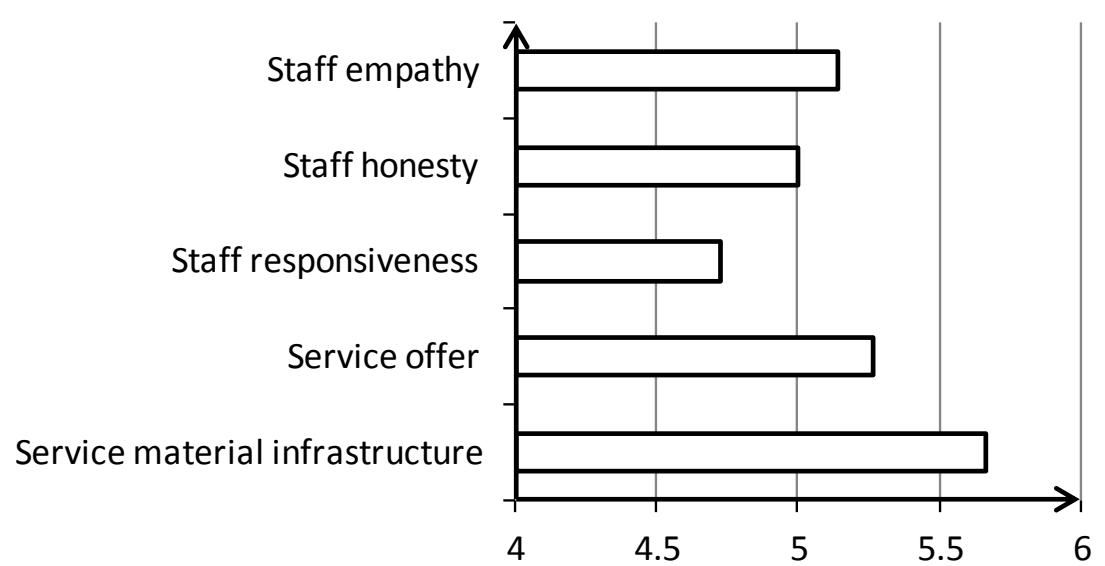

Average values of individual group of determinants

Fig.4 Average values of individual group of determinants.

Source: own study

Analyzing Figure 3 it can be immediately noted that for customers of the research translation office, the group of the most important determinants are the determinants connected to the service offer. Staff empathy and staff honesty were two groups evaluated as the least important between all groups of determinants. It can be concluded that for the customer, it is important that the translation office could perform the translation of various types, in different languages. Other things are not so important. Especially that often customers order translation via Internet. So they often do not see the office or do not have direct contact with employees of this office.

However, from Figure 4 it can be seen that the highest evaluated group of determinants is service material infrastructure. Most of the customers have visual memory and their first impression about the office often affect the overall evaluation of the product or service. 
The total average value for all determinants was also calculated. This calculation was made in two different ways: as an arithmetic average XA and as weighted average XW.

$$
\begin{aligned}
X A & =5.18 \\
X W & =5.16
\end{aligned}
$$

On average, determinants were evaluated at 5.18, after taking into account weights the average was 5.16 (it was not too much lower than the arithmetic average). It means that the determinants were evaluated at a level above the average (over 5 points). Referring both averages to ideal evaluation, it was $73.95 \%$ and $73.73 \%$. It means that the translation services offered by the research company on average approx. $74 \%$ meet customer expectations.

\section{Conclusion}

The service quality analysis is very important due to the development of the service sector in the Polish and world economy, and also because of the difficulty associated with the fact that services have non-material form and it is often difficult to tell what really is evaluated. The service quality and its analysis are completely different from the products quality. Therefore, to analyse the service quality separate research methods, such as Servqual, or its variant Servperf method were created.

In the article to evaluate service quality in the chosen the translation office X, which is located in Czestochowa, the Servperf method was chosen.

The conducted research let show that the customers, who decided for the translation services of the research company, on average estimated that these services in about $74 \%$ met their expectations. The determinants that had the highest positive impact on the results were: statement 4 , that the research translation office has a well-organized website; statement 5, that in the research translation office customers can place orders and 
settle over the Internet; statement 7, that the research translation office also performs sworn translations and statement 11, that interpreters working in the research translation office have appropriate education and qualifications to do their job. The determinant that had the lowest positive impact on the results were: statement 13 , that the research translation office performs each order in time in which it has committed. The determinants which were low assessed should be taken into account by the management of the research translation office in order to improve the quality of its services. For customers offer of the research translation office is the most important group of determinants.

\section{Bibliography}

1. GARCZARCZYK J. 2000. Jakość ustug bankowych i ubezpieczeniowych. Diagnoza, determinanty, segmentacja. Akademia Ekonomiczna, Poznan.

2. GILMORE A. 2003. Services Marketing and Management. Sage. London.

3. INGALDI M. 2015A. Analiza jakości ustug w firmie przewozowej. Logistyka. No 6, pp. 142-146.

4. INGALDI M. 2015B. Evaluation of Service Quality in the Brewery with Use of the Servperf. [in:] Borkowski S., Rosak-Szyrocka J. (ed.) Quality Improvement Practice in Different Branches. Oficyna Wydawnicza Stowarzyszenia Menedżerów Jakości i Produkcji, Częstochowa 2015, pp. 111-122.

5. KUCIŃSKA A. 2007. Ocena skuteczności SZJ jako narzędzie jego doskonalenia. Problemy Jakości, No 5, pp. 17-21.

6. KuCIŃSKA A., KoŁOSOWSKI M. 2009. Zastosowanie metody SERPERV do oceny zadowolenia klienta. [In:] Konferencja Innowacje w Zarządzaniu i Inżynierii Produkcji, Zakopane.

7. Stома M. 2012. Modele i metody pomiaru jakości ustug. Q\&R Polska Sp. z o.o. Lublin. 